intellectual freedom. The knotty problem of censorship vs. selection is solved as the reader of Asheim's "Not Censorship, but Selection" (a speech delivered at the Whittier Conference on Intellectual Freedom) would expect; indeed, in many respects, this book is an amplification and detailed application of the general theories which the author so cogently expressed at Whittier. (See "Polemic Literature," pp. 37-40, and "Gifts," pp. 43-44, in the chapter on religion; the discussion of "popular" and pseudo philosophy, pp. 87-88; the account of censorship in the art department, pp. 141-43; and "The Question of Censorship" in the chapter on literature, pp. 260-62.)

Each chapter in this book begins with a definition of its field and an admirable summary of its history and literature. Then, in varying order for each field, are discussed classification and cataloging of materials, book selection and its problems, the different kinds of libraries and library service, and reference work (including an account of the different types of reference works in each field). Audio-visual enthusiasts will be happy with the amount of space and attention given to a consideration of the place of nonbook materials in libraries (Asheim is for them and for the increasing provision of non-book materials and services by public libraries) and for the able discussions of the problems of picture, record, and film collections in art, music, and literature. A list of the representative reference tools in the field concludes each chapter. These lists of reference works are carefully selected, generally up-to-date guides to the best reference works in the humanities and are alone worth the price of the book to most libraries. For example, the Bibliographie de la philosophie (now also bearing the English title, Bibliography of Philosophy) has been an abstract journal for books only since 1954. No mention is made of this in the book. Philosophic Abstracts is described in the text as of limited usefulness because of its restricted scope; in the list one finds that it was discontinued in 1954. Relatively few instances of this kind occur, however, and, in general, the lists are up-to-date as of the middle of 1956 .

Some of us who still believe that history is one of the humanities might quarrel with the decision to omit that important field from this book. We can only suppose that history has been placed with the social sciences and mourn its loss from the volume now available. Though few historians tend to think of themselves as social scientists, librarians seem generally to have come to the conclusion that history is a social science. Undoubtedly good reasons can be advanced on either side of the argument, and in the present instance there can be no quarrel if the treatment of history in the promised social science syllabus is as excellent and library-oriented as the chapter on religion or philosophy in this.

The book is a good example of offset reproduction from typewritten manuscript, a method of printing adopted by the ALA for publications it does not expect to sell well enough to pay for the cost of letterpress. The present reviewer hopes that this prognostication of the book's success will not be justified. If every librarian who could use it to advantage or learn from it how better to serve his public would buy it, The Humanities and the Library would speedily go out of print.-Fredric J. Mosher, School of $\mathrm{Li}$ brarianship, University of California, Berkeley.

\section{Library Cooperation}

The Hampshire Inter-Library Center: A Survey of Its Background and Its Problems, with Recommendations for the Future. By Keyes D. Metcalf. South Hadley, Mass. The Hampshire Inter-Library Center, 1957. 31p.

The first half of this publication is devoted to principles and theory of collecting of resources in academic libraries. Axioms expressed or findings noted by Metcalf will be generally acceptable, since they appear to reflect the experience of American libraries as a whole. Incisively, the author has (1) indicated the differences between the college and the university (or research) library, (2) pointed out the problems of selecting books to meet the needs of a particular institution, and (3) suggested the avenues of cooperation which are directed at serving the needs of the particular users, and, at the same time, are economical. The remainder of this valuable brochure is devoted to the special 
interests of the Hampshire Inter-Library Center (Amherst College, the University of Massachusetts, Mount Holyoke College, and Smith College), which was founded to provide helpful and economical library services among its members.

Metcalf's proposals concerning the Center are related to the assumptions he developed in the first part of the report. These may be summarized as follows:

1. Libraries - particularly research libraries -tend to grow more rapidly than other parts of education institutions, and to grow cumulatively.

2. Unit costs in libraries tend to increase rather than decrease as collections grow larger.

3. When a library gives improved services it almost invariably stimulates increasing demands for service.

4. The total cost of library operation tends to increase more rapidly than the cost of other parts of an educational institution.

5. The library serves a number of different needs, and providing for some of these needs is much more expensive than for others.

6. The average undergraduate spends well over three-fifths of his reading time on books assigned or specifically suggested by faculty members.

7. A library of from 50,000 to 100,000 volumes will normally take care of this type of reading.

8. More than 80 per cent (and, in some institutions, 90 per cent) of the average undergraduate's use of the library has been accounted for by his use of textbooks and of collateral readings listed for courses.

9. The importance of the remaining 10 or 20 per cent of the undergraduate reading (general reading, toward preparation of special reports, senior theses, etc.) should not be minimized.

10. This type of reading is important for preparing students for graduate work, and requires a larger collection than that needed for the usual type of undergraduate reading.

11. A large colection is even more valuable to faculty members than to students.

12. A good library collection is useful in attracting strong faculty members. (Paul Buck is said to equate this to an inducement of $\$ 3,000$ annually.)
13. A liberal-arts college with 1,000 students can provide basic undergraduate library facilities and services for $\$ 35$ per student annually, and this figure can be reduced as the student-body increases in size.

14. Selection of books for a college or university library-particularly beyond the basic undergraduate need-is not an exact science.

15. There is no limit to what a library might acquire if all wishes of faculty members and advanced students were heeded.

These problems suggest to Metcalf that the institution faces a dilemma in its library. It must either be ready to provide an increasing percentage of total resources, if the library is to meet the demands upon it; or, if it does not, the library must deteriorate in its quality and services. Metcalf observes that funds are sought after competitively by the various parts of the institution, and the growth of the library budget is reflected in a reduced percentage available for faculty salaries and other purposes. It would seem that one could approach this problem of budgeting in a more positive frame of mind if the library had been accepted as a principal axis of educational activity.

Metcalf's observations are generally based on common sense derived from long experience with academic libraries. But such observations may fall short of reality. Some may wish to quarrel with his estimates of the amount of use of materials, and with his $\$ 35,000$ basic library budget for a college with 1,000 students-a budget which "can be reduced as the student-body increases in size" (p. 10). One is hard put to see how this figure can be reduced in total quantity, as more demands are made upon the library in terms of increased enrollment. Perhaps the proportion may be reduced. Although institutional needs vary considerably insofar as library needs are concerned, the $\$ 35$ per student allotment must be regarded as a "low" basis of support. The figures in the "College and University Library Statistics, 1955-56," in the January, 1957, issue of $C R L$, show that for a median group of 1,316 students a median total operating budget was $\$ 60,610$. Perhaps the libraries with about 1,000 students were spending more than was necessary on library services, but it is un- 
likely. It depends, of course, on what kind of library service is being provided. There were expenditure-per-student lows of $\$ 14.77$, $\$ 8.14, \$ 11.21$, and $\$ 12.96$ for the four groups of libraries in the CRL statistics. It is questionable if these institutions are well served by their libraries. In library service, as in most things, you get what you pay for, even though there may be occasional bargains.

Against the background of principles of college library service, Metcalf outlines a program for cooperative library service which would widen the scope of the Hampshire Inter-Library Center to include as associate members Dartmouth, Trinity (Hartford), Wesleyan, Williams, and the Forbes Library in Northampton. Associate members would provide entries for a partial union catalog, make materials listed in such a cata$\log$ available to faculty members and advanced students of the member and associatemember institutions, determine if materials are in the Center before applying elsewhere for interlibrary loans, and consult with the Center's catalog before new subscriptions are placed for highly specialized serials, before purchasing back files of serials, and before buying books of the kind listed in the catalog. Deliberate purchasing of materials would not be prevented, but the librarians would know when they would be duplicating. It is estimated that the partial union catalog would cost $\$ 12,000$. A possible budget for the Center for a year in the early 1960's would be $\$ 40,000$, not including income or expenditures made possible by grants, endowments, or the sale of duplicates.

Again, Metcalf out of his experience cautions against "dangers that call for continued vigilance." These involve those difficulties which "arise inevitably from the nature of libraries, academic institutions, and human beings." Cooperation is a two-way street, and the idea of competition must be submerged if it is to be furthered. Metcalf suggests that "administrative officials and librarians are perhaps more likely than professors to regard other institutions as rivals of their own and to be impatient with the restraints on complete freedom of action that are bound to be entailed by cooperation." This is an interesting hypothesis, since many librarians believe that professors are likely to be more concerned than anyone else. The important point is to make sure that the "human beings" involved in the cooperative project understand fully what is being planned, and how the individual institution will benefit by the project. Oiling and repairing are just as important here as in the care of any other machine.

The Hampshire Inter-Library Center in its six years of existence has been a demonstration of cooperation which suggests enlargement of scope. It would seem that some time in the future it may be useful to have a complete study of the use to which materials in the Center have been put. Undoubtedly, "the Center is making each dollar go further than it would go if spent by an individual library."-Maurice F. Tauber, Columbia University.

\section{Documentation and Information Retrieval}

Documentation and Information Retrieval:
An Introduction to Basic Principles and
Cost Analysis. By J. W. Perry and Allen
Kent. With a Foreword by J. H. Shera.
New York: Press of Western Reserve Uni-
versity and Interscience Publishers, Inc.,
1957. 156p. $\$ 5.00$.

A long-standing need for critical analysis of information retrieval in the present and potential states of the art is recognized in this monograph. The need is not fully met, but as a first attack the approach is praiseworthy.

A mathematical model system is set up, with formulations which are comprehensible to common minds. Indeed, the mathematical presentation is plainer than the verbal explanation, which uses too many words. Judicious verbal pruning would have improved clarity.

Cost analysis difficulties have long handicapped practitioners of information retrieval who preach the necessity of a cost-performance analysis before approving a system or project. The chapters on cost analysis in this monograph will give aid and comfort to these apostles of analysis. The critical faculty is exercised, as is necessary for such analyses, but not far enough. There is no adequate recognition of the intangible factors which 